\title{
A broken link: two generations in a rural household in Massinga district, southern Mozambique
}

\author{
Albert Farré \\ The Human Economy Project, Faculty of Humanities, University of Pretoria, Private Bag x20, Hatfield, Pretoria, 0028, South Africa \\ fantura2@hotmail.com
}

\begin{abstract}
Labour migration has long been a recurrent topic in southern Africa, owing to the appearance of industrialised mining production in the mid-nineteenth century, and its overall effects on land and agriculture. In Mozambique, historically one of the main suppliers to mines, the debate on labour migration has been a constant one. I draw on fieldwork research done in southern Mozambique to show the impact of a change in recruitment policies by the South African mines in the 1970s, and how the consequences last until the present. I suggest that the case study presented here helps us to build a broader picture on migration processes in southern Africa, as well as to be aware of the regional challenges underlying local realities.
\end{abstract}

Keywords: migration, household economy, mine dependency, Mozambique, Southern Africa.

In this article I present the story of a Mozambican mineworker whose son I have come to know well. This man was called Handela, and had his home in Massinga, one of the districts of the southern province of Inhambane. Handela died in the late nineties. However, in 2006, when I first went to Massinga to do fieldwork, I was still able to get information about him from the people among whom he had lived. Handela was remembered as being one of the last 'career' miners in Massinga. Like many of his contemporaries he had spent most of his adult life working in the mines in South Africa. This had allowed him to build a brick house in rural Massinga, take two wives, and head a large and well organized family. One of Handela's sons is called Flex, and he has been my main informant about Handela's life. Flex was born in the late seventies, and grew up in the stable and predictable home environment Handela provided. $\mathrm{He}$ and his brothers intended to follow their father and become migrant workers on the South African mines, but they were unable to do this. The object of this article is to explore the significance and repercussions of the difference between Handela's career and those of his sons such as Flex.

When I first met Flex in Massinga in 2006, his sole source of cash income was from casual work as a driver. He had a driving licence and told me that, in the past, he had used his father's old Land Rover to do some transport business. But when the vehicle broke down irreparably some months before his father's death, Flex could only take to Massinga's sandy tracks when hired by someone else. When not hired as a driver, Flex was obliged to assist his wife with subsistence farming.

Inhambane province has never had a very dynamic labour market. It was a labour reserve for the South African mines for most of the $20^{\text {th }}$ century, with many generations of its adult male residents migrating for wages to the mines (Brochmann 1985, Covane 200I, Lubkemann 2009). As in many other areas in the southern African region, miners were required to sign on for long contracts lasting up to 12 months, and when one contract came to an end they were forced to return to their rural homes in order to sign on for another.
Many households in rural Massinga were trapped in direct dependence on the wages earned in the mines (Van den Berg 1987). In their case the amount of money the migrant workers sent home was spent by the members of their households entirely on food and other necessities of life, leaving nothing to support local agricultural production or other income-generating activities. Other households, of which Handela's was an example, were able to use part of their wage remittances from absent migrants and to improve their situation, at least for a period of time.

Some aspects of the circumstances of Handela's household can best be understood by reference to the analysis put forward in First's (1983) book Black Gold, which was based on a large survey conducted in Inhambane province in 1977. This survey was the first research initiative by the Centre of African Studies (CEA) at Eduardo Mondlane University.

\section{Mozambican worker-peasants}

The survey undertaken by the CEA (1977) led the group of local and expatriate researchers involved under the direction of Ruth First to distinguish between two main categories: poor and middle peasant households. The poor households were those which were wholly reliant on cash remittances to buy food and other basic necessities. They were in the majority and were seen as being trapped in the exploitative migrant labour system. The middle peasant households were those which, as a result of investing part of the money their absent migrant workers earned in the mines in local agriculture or other productive avenues, managed to improve their lot by covering some or all of their food needs and earning some additional cash income. This position was attained through the acquisition of some means of production (such as ploughs and oxen, sewing machines, or construction and carpentry tools). First however makes it clear that the story of the 'middle peasantry' was not one of a gradual trajectory towards independent commodity production. The rural economic activities of these households were deeply integrated in the migrant wage labour system. Active members of these 
households were defined by First as 'worker-peasants' (First 1983: 183-194): they were (waged) workers when they spent time in the South African mines, and peasants (but also shopkeepers, traders and transporters) when they were back in their home areas. Individual members were inserted into a wider household economy that often enabled these two activities (those of waged workers and rural producers) to take place at the same time. As the men involved in mining sent their remittances to their rural households, other family members at home were providing the labour necessary to make those investments from remittances viable.

The crucial point here is that First's work compellingly stressed the inherent interrelation between the regional mining labour system and small-scale agricultural production and other business activities in the rural areas. Despite the enormous distortions introduced by the South African mining economy, economic activities in rural Mozambique were in fact sustained by that exploitative and oppressive system. Economic life in Inhambane's rural areas and wage labour in South African mines were two sides of the same coin (First 1983: 185, Neocosmos 1993:45).

Rich households - defined by First as those who could afford to hire salaried labour on their agricultural estates were virtually non-existent. First found only two of those in the whole Inhambane province. Their members were related to the previous Portuguese settler families, who constituted the bulk of rich agricultural commodity producers before independence and relied on forced labour for their capital accumulation (First 1983:128). At independence land was nationalised and private property rights abolished and replaced by use rights (De Quadros 2003). Portuguese settlers left the country en masse and the land previously occupied by them was redistributed or spontaneously reoccupied. First did not detect any absolute shortage of land and as a consequence there was no class of landless peasants (1983:128). At the same time, better-off peasants did not have enough resources to pay for wage labour and could not rely on forced labour like the Portuguese settlers. The national policies introduced by the new liberation government led by Frelimo' from 1975 onwards also worked against the formation of a class of independent petty commodity producers in the rural areas. The conditions for the formation of a new class of rich peasants to replace the Portuguese settlers were simply not there.

At the 1977 Third Party Congress, Frelimo adopted a stance that advocated rapid modernisation and industrialisation of the country's agricultural-based economy through state-centred accumulation. The basic dualism upheld by Frelimo conceived of peasants as all grouped in one category as part of a precapitalist mode of production which needed to be modernised. Led by the state, the 'modern' economy would eventually absorb the 'backward' subsistence economy (Dinerman 200I:I44). Modernisation of the rural areas was to be driven by the creation of large mechanized state farms (O'Laughlin 1981, Wuyts 1981), complemented by agricultural co-operatives run by communal villages (Wardman 1985, O'Laughlin 1996, Bowen 2000). The agricultural co-operatives were conceived as the main tool to make small-holder peasants productive by pooling together their labour and land resources. From the outset state farms received the bulk of the national budget for agriculture, and those working there were to be paid a wage. The co-operatives were run by unpaid family labour using low-tech equipment (ploughs and oxen, hoes) and local seeds.

The Third Congress line on agricultural policy was dualist in another sense also: it conceived of the middle peasants identified by the CEA as 'protokulaks' and enemies of the revolution (Dinerman 200I:I46), in other words petty capitalists who needed to be disciplined and reined in under the new communist dispensation. The new policy purportedly supported poor peasants. The middle peasants were 'punished' by having to donate all their assets to the newly formed agricultural co-operatives. Middle peasants would be forced to choose between going to work on the state farms, where they would receive lower wages than they had in South Africa, or joining an agricultural co-operative, in which case they would be required to donate the assets they had acquired by investing their remittances in small-scale economic activities.

The CEA report was released against the backdrop of the Third Congress line (Dinerman 200 I: |43- |44). Its aim was to address some of the shortcomings of Frelimo's stance on agricultural policy. The CEA researchers stressed that, far from being inserted into an insulated archaic mode of production, the majority of Mozambican poor peasants struggled to meet their subsistence needs and were heavily dependent on wage remittances from South Africa for their basic needs. In addition, the focus on the middle peasantry showed that the economic activities in the rural areas did not show signs of an autonomous capitalist sphere led by 'protokulaks', but were subordinated to the regional migrant labour system. The CEA researchers (1977) and First's own work (1983) further stressed that there was no absolute distinction between the middle and the poor peasant strata. Changes in circumstances or in the life cycle of the household could easily push middle peasants into the poor category, or vice versa (First 1983:I3I). According to the CEA, the middle peasantry was no enemy of the revolution, but the backbone of agricultural production in the rural areas waiting to be co-opted in the new nation-building project. The researchers recommended that in virtue of their skills they be given a special role in the newly formed agricultural co-operatives. From an ideological point of view, the middle peasants were ready to join the socialist project because of their status as workerpeasants: their consciousness was shaped by their experience in the mines and was much closer to that of the poor peasants than Frelimo envisaged (CEA I977:IV.9).

Handela's household was an excellent example of the middle peasantry category. He had started his career as a migrant worker in the Johannesburg gold mines in the mid1960s. At this time he was still unmarried and in the breaks from mining work he lived in his father's house. The father too had been a migrant worker in South Africa and retired around the same period. From this point onwards, Handela's father worked full-time in his agricultural activities. Handela sent remittances to his father's home and his contribution

I. Frelimo is the Portuguese acronym for Mozambican Liberation Front. 
actively supported the father's agricultural activities. In turn, the proceeds of these activities provided the necessary resources, including the brideprice (lobolo), needed for Handela's first marriage with Flex's mother. For a period Handela's new wife lived in his father's house, while he returned to the mines to earn the money needed to build his own independent household. He built his home in the early 1970s on a site a short distance from his father's. The first dwelling was small and in the traditional style, but he was already making plans to build a larger structure when his resources permitted. In the meantime, he purchased an iron plough and a small mill for grinding grain to begin his own farming activities. His children were still too young to assist with the farming, but the reciprocal relation with his father continued and the father provided assistance to plough Handela's fields and harvest the crops. His father teamed his own oxen with Handela's plough and rented out the plough and the mill to other neighbours. Handela's brothers were involved in providing labour, equipment and cash for these family economic activities, but Flex told me that he had been too young at the time to recall any of the details of these arrangements now.

This period in Handela's economic life clearly shows the interdependence between the rural activities and the mine labour system. Despite the struggles and the challenges Handela and his father had to face in a foreign country that systematically exploited them as cheap labour and temporary second-class residents, they managed to make the best of their condition and their efforts in the mines led to a gradual expansion of their household economies. As highlighted in First's work, this was not a linear trajectory towards autonomy from the mining labour system. At all stages of the gradual expansion, remittances were needed to move to the next step. There was a circular element at play where Handela's father redeployed his labour after permanent retirement from the mines into the economic activities in Massinga, while Handela replaced the father's role by becoming the primary provider of remittances from the mines.

\section{Changes in the South African regional economy and the failure of state socialism}

The pragmatic adaptation of the Mozambican middle peasantry to the harsh reality of the migrant labour system was however under threat. The CEA researchers led by Ruth First were ideologically aligned with Frelimo's intention to break away from the yoke of South African economic domination on the Mozambican internal economy. Frelimo soon became involved in the Front Line States' strategy to isolate South Africa's racist regime (O'Meara 199I).

But First and her colleagues highlighted that there were other factors that had already put into motion a drastic and permanent reduction of Mozambican labour in the South African mines. Since the 1960s, South African mining companies started to shift from labour-intensive to capital-intensive mineral extraction. The number of low-skilled underground workers was destined to decrease as a result. By introducing mechanical means of underground transport, for instance, large numbers of unskilled workers could be replaced by fewer skilled workers. Since the mid-1970s, South Africa also moved towards a policy of internalisation of the mining labour force. Workers were increasingly drawn from the
Bantustans to counter the alarming unemployment rates there. This trend occurred at the expense of foreign workers. At the same time, the mining industry aimed to increase wages for black miners, especially in the gold sector following the sharp rise of prices after the demise of the fixed controls of the Bretton-Woods system, and to stabilise its foreign workforce by relying on a smaller number of more permanent workers with higher levels of skills and experience. As a result of all these factors combined, the number of Mozambican workers in the South African mines steadily decreased starting from 1976.

First and her CEA colleagues noted that if Frelimo did not provide sustainable solutions to replace dependence on the exploitative, yet sturdy, mining labour migration system, the effects for most Mozambican peasants would be disastrous. The final recommendation of the 1977 report rightly warned that droves of young men would move to the cities, swelling the ranks of the unemployed, unless enough employment was created in the national economy. State farms struggled to be productive and did not absorb the growing number of unemployed youth who could not find work in the South African mines.

Meanwhile, without substantial state support, the cooperative experiment was destined to fail. The vast majority of peasants experienced major shortages of consumer goods, agricultural equipment and other resources they had come to depend on during the colonial period (Dinerman 2001:144). This paradoxically meant that the original 'anti-middle peasant line' was never fully enforced, as even those middle peasants who initially joined co-operatives could still later return to their own individual fields (Dinerman 200 I: 148) - a wholesale attack on the 'protokulaks' never quite materialised. Over the years, co-operative production developed more as an 'appendage' than an alternative to family farming (Bowen 2000: I53, Dinerman 200I:I48).

\section{Social differentiation in the Mozambican countryside}

The changes in the South African mining industry initially favoured Handela and his household. As a team leader with ten years' experience on the gold mines, Handela was one of the men who continued to be recruited to work in South Africa, at significantly higher wages than before. The failure of the state to coerce middle peasants to give up their assets to the agricultural co-operatives meant that the 'anti-middle peasant' line had little impact on Handela's household. Flex was too young at the time to remember whether Handela's household had at least formally joined one of the local co-ops. But the fact that throughout the 1980s Handela continued to retain his home and cultivate his fields is well in line with Bowen's (2000) finding in her study of the first wave of cooperatives set up after the Third Congress in a small island in Maputo Province, Illa Josina Machel. After middle peasants involved in the co-operatives realised that the government was not giving any priority to their development, they gradually abandoned the collective enterprises and returned to their individual fields, which had not been expropriated by the new government structures.

While Handela's household and other middle peasants took advantage of their privileged position in the mines, most 
other peasants in Massinga were feeling the bite of the new state policies. Social differentiation in the countryside was definitely on the rise. Handela and a few others were able to build large brick houses, in the Portuguese colonial style. His house, which still stands, had several rooms, cement floors and a flat roof. Flex recalls that Handela was particularly proud of the large water tank he built on top of the flat roof. It was connected to plumbing inside the house, and provided Handela's family with abundant running water on tap. Although Handela's father passed away in the early 1980s, his farming activities continued to prosper. His own children, including Flex, were now of an age to contribute their labour to ploughing, weeding and harvesting the fields. Handela acquired his own draught animals and increased the size of his fields, allowing him to earn more cash locally by selling his growing surplus. In the mid-1980s he married a second wife. Both wives lived in the new house. He also bought the second-hand Land Rover which Flex learnt to drive. He purchased it in South Africa and drove it back to Massinga in order to start his own small transport business. Mirroring the previous partnership between Handela and his father, Flex worked for Handela and used the Land Rover to drive people and goods from the countryside to Massinga town and back.

\section{The civil war and the end of the worker-peasant era}

The escalation of the civil war had more of a negative impact on Handela's family fortunes. The civil war broke out in 1977 between Frelimo and Renamo, ${ }^{2}$ the opposition movement actively supported by the South African racist regime. The conflict escalated over the years and further exacerbated the negative effects of Frelimo's failed economic revolution on Mozambican peasants. As the general situation in Mozambique worsened in the course of the 1980s, Frelimo found it more and more difficult to get people to comply with their socialist policies, and it ended up relying on violent methods not very different from those used by the colonial authorities. Violence was applied to keep people living in the communal villages (Borges Coelho 1998), force people to work on the state farms (Dinerman 1999) and transfer unemployed youth from the capital city to rural areas in order to increase the quantity of food produced (Raimundo 2009). Another paradox of the situation was that despite its reactionary politics and violent methods, Renamo increased its support among peasants disillusioned by the failures of state socialism.

The war began in the central part of the country and by the mid-1980s had reached all of its corners. Renamo managed to establish two small but permanent bases in Massinga district in 1986 and to hang on to these until the end of the war in October 1992, bringing high levels of insecurity to most of the district's inhabitants. Flex told me that the primary school he had attended a few years earlier was destroyed in the late 1980s. Any vehicle travelling along the national road in the district could become a Renamo target.

Handela and his family had avoided the worst effects of the civil war for the most part of the 1980s, but by the end of the decade they were forced to abandon their home and fields. This happened just after Handela had decided not to seek a new contract in Johannesburg. He had made the decision to retire permanently to the countryside and dedicate himself to his rural economic activities. Like other people in the area, he fled with his family to Massinga town for protection. Many of those displaced in those years never came back to their original homes. Despite the setback, Flex recounts that Handela was determined to return to his home and resume farming and business as soon as he could.

When he returned to his home, however, he realised that his family fortunes were turning forever. The same changes that had put him in a privileged position as a better-paid, experienced miner were now revealing their devastating effects on the social and economic reproduction of his family. Handela had always intended for his sons to follow in his footsteps and become migrant workers in the South African mines. He had initially blamed the fact that Flex's older brothers had not yet done so on the disruption caused by the war. But with the conflict heading towards the end, he had to face the bleak reality that, as young people with no relevant experience, his sons would not be able to secure contracts to work in South Africa. Massinga's time as a labour reserve for the mining industry had come to an end, and, with it, Handela's plan to repeat the same cycle initiated by his father. In the absence of active remittances from the mines, Handela's family activities were drastically curtailed and the future of his children compromised.

The analysis of Ruth First (1983) and her colleagues (CEA 1977) had proved correct: the fragile equilibrium that enabled middle peasants to retain their position of relative wealth vis-à-vis poorer households could not be maintained without a viable replacement to the South African migrant labour system. Middle peasant households like Handela's quickly fell into the poor peasant category, swelling the ranks of the vast majority of Mozambican peasants struggling to get by after the drastic reduction of employment in the South African mines.

\section{Back to the bottom: Handela's widows and children today}

When I began fieldwork research in Massinga district in 2006 I had the opportunity to live in Handela's house. It has three bedrooms, one dining room, a kitchen and a veranda. But the house was virtually derelict by then. The water tank on the roof - Handela's pride and joy - did not work anymore and the water leaked through the ceiling into the dining room. I saw the remains of Handela's old Land Rover parked outside the house, but its wheels were missing and its engine was rusted to a lump of indeterminate metal.

Handela's two widows, Landi and Kezani, were still living there. They were living alone, as most of their sons and daughters had dispersed, some to Maputo, some to Beira (the second most populous Mozambican city), others to South Africa. None of Handela's migrant sons had stable jobs that allowed them to send remittances to their parents. They did not manage to build their own independent homes in Massinga district. As a consequence, Landi and Kezani had no daughters-in-law in the vicinity to help them with agricultural work. Flex and his wife helped from time to time, but Flex's

2. Renamo is the Portuguese acronym for Mozambican National Resistance. 
wife was understandably reluctant to take the burden of feeding two households while Flex himself struggled to secure a stable income. Since Handela's retirement, the family's reproductive cycle had irreparably broken down. While Handela had been alive, he was able to motivate and discipline the family members to work together. When he died, the family economic activities in the countryside rapidly came to an end.

I first came to his house thanks to a colleague of mine whose family is originally from Massinga district. I informed Luis, an economist in Maputo, that I was keen to do some fieldwork in the countryside. He told me he knew a place where I could stay. We drove for almost 500 kilometres from Maputo to Massinga district, and Luis took me to Handela's house. As we approached it, he said: "You see, it may need some layers of paint, but this is a nice house. Nobody manages to build this kind of house nowadays."

As we handed over a fifty kilogram bag of rice and five litres of Portuguese wine we had brought for Handela's widows from Maputo, Luis told me the arrangement he had made for me. "As you can see there is an empty room in the house. You can stay here as long as you want. The mamanas a colloquial term for women who are mothers - will cook and wash your clothes." I was not going to pay rent, but instead I would contribute to buying cooking oil, bread, soap, sugar, butter, tea, and other household goods the widows needed. Luis added: "When you decide to leave this place, try to make sure that their store is full."

Landi and Kezani had some cassava and groundnuts which they grew on their small plots. They also grew some lettuce and onions in a garden close to a nearby swamp. They had access to plenty of coconuts, which in Inhambane are an important cooking ingredient. They needed to buy everything else, but they had no income. It became painfully clear to me that these two women, living in a crumbling house equipped with a rusty grinding mill, had descended into dire poverty. They were poorer than the households in the bottom category identified by First and her colleagues in 1977. While the poor households back then could still rely on the mining remittances for their basic needs, the widows were currently engaged in a daily struggle to put food on the table.

Their prospects and those of their neighbours were bleak. The young fled the countryside without knowing exactly where to go. The elderly remained, knowing that the young were unlikely ever to come back and would not be able to help with their subsistence. In conversation with Flex and Handela's widows, the past was a recurrent theme. Their words were tinged with nostalgia. In one of our long chats about Handela's life, Flex said: "When I look at my father's house, I think that we had it good back then, when the mines were hiring. Look at us now, we are going backward."

What was the object of Flex's nostalgia? Was he nostalgic for the brutal racist exploitation carried out by the South African mines? Did he regret having missed the heights of apartheid oppression? As Jacob Dlamini (2009) highlighted in his analysis of South Africans' emotional attachment to their country's past, nostalgia is not synonymous with a political endorsement of apartheid and colonial rule. Flex was nostalgic for a time when, despite major structural challenges and systematic discrimination, people had the option of using the cash earned in the mines to carve out a space of relative autonomy and stability in the rural areas. Their rural homes were seen as a desirable haven from the stress of modern life, rather than a wasteland to be left behind as soon as possible. Flex was nostalgic for the era of the worker-peasant, when people from Massinga with enough determination could work hard to secure a relatively comfortable retirement. It was not much, but definitely more than they have now. Nor did everybody share equally in this dire predicament. Somewhat replicating the highly unequal structures of colonial society, a few rich households accumulated wealth under the patronage of political elites, while everyone else struggled to feed themselves.

Flex's disappointed expectations, then, are neither 'expectations of modernity' (Ferguson 1999) nor expectations of 'rurality'. Flex and his contemporaries would much prefer something similar to the fragile equilibrium guaranteed by the interactions between the regional mining economy and the rural areas than the precarious lives they live today. In the name of efficiency and integration into the global free market, the current neo-liberal dispensation has given up on any kind of long-term commitment to workers and their families.

In their assessment of the future of mine migrancy in southern Africa published just one year after the first free elections in South Africa, Davies and Head (1995) point out that:

In terms of the numbers involved, legal movement to the mines is, in fact, no longer the main form of migration to South Africa. Many more people are now involved in clandestine and illegal migration. [...] The only reliable figures available are for deportations. Although these represent only the tip of the iceberg, they are telling enough. They indicate that more than half as many people were deported from South Africa in 1992 as there were citizens of neighbouring countries working legally in the mining industry $-96,515$ against 174,652 . (1995:439-40)

Davies and Head warn us that even with the region finally being freed from the dark clouds of the past - apartheid, the cold war, undemocratic governments imposing their will on the people - there is still a big elephant in the room. The mining labour migration system has been so important in the development of regional capitalism that it cannot be ignored when addressing contemporary issues of growth, equality and sustainability in southern Africa.

Davies and Head insist that the region has to be considered as a whole, because no national policy can provide solutions for single countries alone, not even South Africa. They conclude their article by saying that "if [changes in the South African mining industry] do result in a sharp and disproportional reduction of employment from neighbouring supplier states, this will not, under existing conditions, be without consequences either for the countries concerned or for South Africa" (Davies and Head 1995:449). They stress the necessity of finding a viable solution to replace the old mining system. My fieldwork experience convinces me that, eighteen years later, this necessity is still felt by people on the ground. The disappearance of middle peasants like Handela 
suggests that the present in Massinga is, if anything, worse than the colonial past.

\section{Conclusion}

By looking at the history of a rural household, I have tried to show the relevance of a broken link between generations in Massinga. This break can be traced back to the 1970s, but its destabilising effects, at local and regional level, were not fully visible until the 1990s. My ethnographic case shows the particulars of Mozambican history in this period as a variation on a broader southern African story. It also shows how the negative effects of the sharp decline of the regional mining recruitment system endure up to the present in Massinga, and are becoming more acute. The main conclusion is that the challenge underlying my case study is in fact a regional one. The problems of unemployment and poverty in southern African are not solvable through isolated national paths. The region needs something as solid and durable as the colonial mining system to address these issues, without repeating the mistakes of the past. Neither I nor my research participants are in any way nostalgic for the racist practices and the structural inequalities of the old system. A viable replacement should be inserted into a more human regional economy that makes pragmatic deals with states and corporations with the primary aim to improve the livelihoods of the vast majority of people, who are struggling today to meet their basic needs and are rapidly losing any hope for a better future.

\section{References}

Borges Coelho, João Paulo. 1998. State resettlement policies in post-colonial rural Mozambique: the impact of the communal village programme on Tete province, 1977-1982. Journal of Southern African Studies 24 (I):6I-9I.

Bowen, Merle. 2000. The state against the peasantry: rural struggles in colonial and postcolonial Mozambique. Charlottesville \& London: University Press of Virginia.

Brochmann, Grete. 1985. Migrant labour and foreign policy: the case of Mozambique. Journal of Peace Research 22 (4):335-344.

CEA. 1977. O mineiro moçambicano: um estudo sobre a exportação de mão de obra. Maputo: Centro de Estudos Africanos-UEM. Online: http://www.ruthfirstpapers.org.uk/pt/content/423
[Accessed 18 August 2013]

Covane, Luis António. 200I. O trabalho migratório e a agricultura no sul de Moçambique, 1920-1992. Maputo: Promédia.

Davies, Robert; Judith Head. 1995. The future of mine migrancy in the context of broader trends in migration in Southern Africa. Journal of Southern African Studies 2 I (3):439-450.

De Quadros, M.C. 2003. Current land policy issues in Mozambique. Land Reform 3:175-200.

Dinerman, Alice. 1999. O surgimento dos antigos régulos como 'chefes de produção' na província de Nampula, 1975-1987. Estudos Moçambicanos 17:95-256.

Dinerman, Alice. 200I. Peasant and state in Mozambique. Journal of Peasant Studies 28 (3): I43-I54.

Dlamini, Jacob. 2009. Native nostalgia. Auckland Park: Jacana Media.

Ferguson, James. 1999. Expectations of modernity: myths and meanings of urban life on the Zambian Copperbelt. Berkeley: University of California Press.

First, Ruth. 1983. Black gold: the Mozambican miner, proletarian and peasant. Brighton: The Harvester Press Limited.

Lubkemann, Stephen. 2009. From circular migrants in the mines to transnational polygynists in the townships: a century of transformation in central Mozambican male migration regimes (1900-1999). International Migration 47 (3):51-92.

Neocosmos, Michael. 1993. The agrarian question in southern Africa and "accumulation from below": economics and politics in the struggle for democracy. Uppsala: Nordisk Afrikainstitutet.

O'Laughlin, Bridget. 1981. A questão agrária em Moçambique. Estudos Moçambicanos 3:9-32.

O'Laughlin, Bridget. 1996. Through a divided glass: dualism, class and the agrarian question in Mozambique. Journal of Peasant Studies 23 (4): I-39.

O'Meara, Dan. 1991. The collapse of Mozambican socialism. Transformation 14: 82-103.

Raimundo, Inês M. 2009. International migration management and development in Mozambique: what strategies? International Migration 47 (3):93-1 22.

Van den Berg, Jelle. 1987. A peasant form of production: wagedependent agriculture in southern Mozambique. Canadian Journal of African Studies 21 (3):375-389.

Wardman, Anna. 1985. The co-operative movement in Chokwe, Mozambique. Journal of Southern African Studies II (2):295-304.

Wuyts, Marc. 198I. Sul do save: estabilização e transformação da força de trabalho. Estudos Moçambicanos 3:33-44. 